\title{
ANALISIS KESALAHAN SISWA DALAM MENYELESAIKAN SOAL CERITA DENGAN FONG'S SCHEMATIC MODEL FOR ERROR ANALYSIS PADA MATERI SISTEM PERSAMAAN LINEAR TIGA VARIABEL
}

\author{
Dhea Dwi Agustin ${ }^{1)}$, Elin Marlina ${ }^{2)}$, Hilda Sara ${ }^{3)}$, Jaka Haerul ${ }^{4)}$ \\ ${ }^{122) 344)}$ Program Studi Pendidikan Matematika, Universitas Kuningan, Jl. Cut Nyak Dhien No. \\ 36A Cijoho, Kuningan, Jawa Barat, Indonesia \\ dheadwiagustin@gmail.com, melinarlina@gmail.com, hildasara28@gmail.com, \\ jakakhaeru198@gmail.com
}

\begin{abstract}
This study aims to describe the types of errors and the factors that cause students to mistake in solving word problems with Fong's Schematic Model for Error Analysis on the material system of three-variable linear equations. This research uses a qualitative research approach. The study participants consisted of 3 high school grade X students in one of the high school in Kuningan. Subjects in the study were selected using a purposive sampling technique. Research data collection using the method of documentation, tests, and interviews. Checking the validity of the data using triangulation techniques, by collecting different data to get data from the same source through tests, interviews and documentation. Based on the results of data analysis, it can be concluded that the types of students' mistakes in solving word problems are operational errors and mathematical themes. Factors causing student errors include: the rush to immediately solve a problem, the lack of accuracy, the habit of working on the problem, forgetting, lack of understanding of the problem, and lack of understanding of the material.
\end{abstract}

Keywords: Error; Word Problems; Three Variable Linear Equation System; Fong's Schematic Model for Error Analysis

\begin{abstract}
Abstrak
Penelitian ini bertujuan untuk mendeskripsikan jenis kesalahan dan faktor-faktor penyebab kesalahan siswa dalam menyelesaikan soal dengan Fong's Schematic Model for Error Analysis pada materi sistem persamaan linier tiga variabel. Penelitian ini menggunakan pendekatan penelitian kualitatif. Partisipan penelitian terdiri 3 siswa kelas X SMA salah satu sekolah SMA di Kuningan. Partisipan dalam penelitian ini dipilih menggunakan teknik purposive sampling. Pengumpulan data penelitian menggunakan metode dokumentasi, tes, dan wawancara. Pemeriksaan keabsahan data menggunakan teknik triangulasi, dengan mengumpulkan data yang berbeda-beda untuk mendapatkan data dari sumber yang sama melalui tes, wawancara dan dokumentasi. Berdasarkan hasil analisis data dapat disimpulkan bahwa jenis kesalahan siswa dalam menyelesaikan soal cerita adalah kesalahan operasional dan tema matematika. Faktor penyebab kesalahan siswa antara lain: terburu-buru ingin segera menyelesaikan soal, kurang teliti, kebiasaan saat mengerjakan soal, lupa, kurang memahami soal, dan kurang memahami materi.
\end{abstract}

Kata Kunci : Kesalahan; Soal Cerita; Sistem Persamaan Linier Tiga Variabel; Fong's Schematic Model for Error Analysis

Cara Menulis Sitasi: Agustin, D., D., Marlina, E., Sara, H., Haerul, J. (2020). Analisis kesalahan dalam menyelesaikan soal cerita dengan fong's schematic model for error analysis pada materi persamaan linier tiga variabel. Jurnal Edukasi dan Sains Matematika (JES- 
MAT), 6 (1), 23 - 36.

\section{PENDAHULUAN}

Matematika merupakan ilmu pengetahuan dasar yang sangat bermanfaat bagi kehidupan sehari-hari. Pengaplikasian terhadap ilmu matematika dan keterampilan penggunaannya merupakan salah satu hal penting dalam kehidupan manusia. Perkembangan teknologi informasi dan komunikasi pun tak dari peran perkembangan ilmu matematika. Untuk dapat mengembangkan, menguasai dan mencipta teknologi di masa depan, diperlukan penguasaan ilmu matematika yang kuat sejak dini.

Matematika sering dianggap sebagai mata pelajaran di sekolah yang memiliki peranan penting dalam membentuk intelektual siswa. Matematika mencakup semua aktivitas yang berkaitan dengan berpikir logis, sistematis dan berhubungan dengan bilangan, konsep dan simbol serta memiliki aturan yang logis yang berfungsi untuk memudahkan berpikir. Baroody (1993) berpendapat bahwa matematika tidak sebagai alat bantu berpikir, namun lebih dari alat penemuan pola, penyelesaian masalah, atau pengambilan kesimpulan, tetapi matematika juga alat untuk mengkomunikasikan berbagai gagasan secara jelas, akurat, dan ringkas. Oleh karena itu, matematika perlu diterapkan pada semua peserta didik di berbagai jenjang pendidikan untuk membekali peserta didik dengan kemampuan berpikir logis, analitis, sistematis, kritis dan kreatif serta kemampuan mengkomunikasikan berbagai gagasan dengan jelas, akurat, dan ringkas.

Pemecahan masalah merupakan upaya untuk menyelesaikan suatu permasalahan yang ditemukan. Menurut Chapman (2006) masalah dalam matematika dapat disajikan dalam bentuk verbal (kata-kata), gambar, simbol ataupun kombinasi dari ketiganya. Masalah matematika yang disajikan dalam bentuk verbal (kata-kata) tidak dapat dipisahkan dari penerapan matematika dalam kehidupan sehari-hari. Masalah matematika dalam bentuk verbal sering kita kenal dengan soal cerita.

Soal cerita penting untuk diberikan kepada siswa dengan tujuan melatih siswa dalam menyelesaikan masalah. Rahardjo dan Astuti (2011) mendefinisikan soal cerita matematika sebagai soal yang terkait dengan masalah kontekstual untuk dicari penyelesaiannya dengan menggunakan kalimat matematika yang memuat bilangan, operasi hitung, dan relasi $(=,<,>, \leqslant, \geqslant)$. Dalam penyelesaian soal cerita terlebih dahulu siswa harus mampu memahami isi soal cerita, selanjutnya menarik kesimpulan objek-objek yang harus diselesaikan dan membuat pemisalan dengan menggunakan simbol-simbol matematika, hingga tahap akhir yaitu berupa penyelesaian. Namun, masih banyak siswa yang melakukan kesalahan dalam menyelesaikan soal cerita.

Kesalahan dalam mengerjakan soal cerita terjadi karena pengerjaan soal cerita membutuhkan keterampilan yang kompleks. Terkadang siswa tidak mengerti maksud soal, tidak dapat menginterpretasikan soal cerita dalam kalimat matematika atau sebenarnya siswa tahu bagaimana menjawab pertanyaan, tetapi kurang teliti dalam perhitungan. Hal serupa disampaikan oleh Rahardjo dan Astuti (2011) bahwa berbagai kesalahan yang dilakukan siswa dalam menyelesaikan 
soal cerita antara lain kesalahan dalam memahami soal, kesalahan dalam melakukan komputasi, dan kesalahan dalam menginterpretasikan jawaban model matematika. Kesalahan yang sering dilakukan siswa tersebut merupakan salah satu penyebab prestasi siswa menjadi rendah.

Berdasarkan hasil kegiatan Praktek Keterampilan Mengajar III pada salah satu SMA Negeri di Kuningan pada materi Sistem Persamaan Linear Tiga Variabel (SPLTV) di kelas $\mathrm{X}$ dapat disimpulkan beberapa hal, (1) masih banyak siswa kelas $X$ di SMA Negeri 2 Kuningan melakukan kesalahan dalam menyelesaikan soal cerita tentang SPLTV; (2) siswa tidak terbiasa mengerjakan soal matematika dalam bentuk soal cerita; (3) guru kelas X mata pelajaran Matematika Wajib sudah berusaha meningkatkan kemampuan siswa dalam menyelesaikan soal cerita salah satunya dengan cara sering membimbing siswa dalam memahami soal dan menjelaskan langkah - langkah pengerjaannya. Akan tetapi hasilnya tetap masih kurang memuaskan. Hal ini bisa saja terjadi karena guru mengatasi masalah ini bukan dari penyebab utama siswa melakukan kesalahan dalam menyelesaikan soal cerita. Hal-hal yang menyebabkan siswa melakukan kesalahan dalam menyelesaikan soal cerita belum diidentifikasi secara menyeluruh sehingga penanganan yang dilakukan kurang tepat sasaran. Akibatnya, hasilnya tidak efektif untuk mengurangi tingkat kesalahan siswa dalam menyelesaikan soal cerita. Permasalhan tersebut sejalan dengan yang di sampaikan oleh Amalia dkk (2018) yang menyatakan bahwa materi SPLTV adalah salah satu materi yang terdapat pada soal cerita yang dirasa sukar oleh siswa untuk menyelesaikannya, dan biasanya disajikan dalam bentuk soal cerita yang menyebabkant siswa kesulitan menemukan penyelesaiannya, terutama karena pada materi SPLTV. Siswa sulit menerjemahkan soal cerita ke dalam model matematika untuk menemukan solusi penyelesian.

Beberapa peneliti telah melakukan analisis kesalahan siswa dalam mengerjakan soal cerita diantaranya Rahayuningsih dan Qohar (2014), Amalia dkk (2018), Farida (2015), Magfirah (2019). Badriyah, dkk (2017), Kholishoh, dkk. (2017). Amalia dkk (2018), melalukan penelitian analisis kesalahan dalam menyelesaikan soal cerita pada SPLTV berdasarkan Newman. Rahayuningsih dan Qohar (2014), melakukan analisis kesalahan siswa dalam menyelesaikan soal cerita SPLDV berdasar analisis kesalahan Newman. Sedangkan Rahayu (20 melakukan analisis kesalahan siswa dalam menyelesaikan soal SPLDV. Farida (2015), menganalisis kesalahan siswa SMP kelas VII dalam menyelesaikan masalah soal cerita matematika. Maagfirah (2019), melakukan analisis kesalahan siswa dalam menyelesaikan soal cerita matematika berdasar prosedur Newman. Sementara itu Badriyah, dkk (2017), melakukan analisis kesalahan dan scaffolding siswa berkemampuan rendah materi operasi tambah dan Kurang bilangan bulat. Kholishoh, dkk. (2017), melakukan analisis kesalahan dalam menyelesaikan soal cerita dengan Fong's schematic model for error analysis pada materi volume prisma dan limas ditinjau dari gender. Sedangkan Nurussata'at, dkk. (2016), melakukan analisis kesalahan siswa dalam menyelesaikan soal cerita pada materi volume prisma dengan Fong's schematic 
model for error analysis ditinjau dari gaya kognitif siswa.

Metode yang digunakan untuk menganalisis kesalahan jawaban siswa, diantaranya metode Newman, Watson, Clements, Clarkson, Fong, dan masih banyak metode yang lain. Namun menurut Kholishoh, dkk. (2017) untuk menganalisis kesalahan siswa dalam menyelesaikan soal cerita lebih baik menggunakan metode Fong dikarenakan pada metode Fong lebih spesifik dalam menganalisis kesalahan. Menurut Fong (1993), model skematik yang menggambarkan kesalahan yang dibuat dikembangkan yang terdiri dari dua level. Tingkat pertama dikategorikan dalam skema strategis. Sehubungan dengan ini, lima kategori kesalahan diidentifikasi: tidak ada solusi, menggunakan prosedur yang tidak relevan, tidak lengkap skema tanpa kesalahan, skema tidak lengkap dengan kesalahan dan skema lengkap tetapi dengan kesalahan. Tingkat kedua dikategorikan sesuai dengan cara klasik klasifikasi kesalahan. Tingkat kedua dianggap dimasukkan di bawah tingkat kesalahan pertama.

Analisis kesalahan dengan metode Fong yang spesifik ini diharapkan mampu untuk menganalisis kesalahan siswa kelas $\mathrm{X}$ dalam menyelesaikan soal cerita terkait dengan SPLTV secara rinci dan mendalam. Hasil analisis tersebut dapat dijadikan bahan pertimbangan dalam merencanakan dan melaksanakan kegiatan belajar mengajar selanjutnya. Harapannya kualitas kegiatan belajar mengajar selanjutnya dapat meningkat. Kemudian, peningkatan kualitas belajar mengajar tersebut diharapkan dapat meningkatkan prestasi belajar siswa.

Upaya untuk mengetahui kesalahan yang dilakukan siswa dalam melakukan penyelesaian soal cerita tentunya tidak dapat dipisahkan dengan faktor-faktor yang menjadi penyebabnya. Analisis kesalahan siswa dalam menyelesaikan soal cerita dilakukan tidak hanya pada identifikasi kesalahan apa yang dilakukan oleh siswa, akan tetapi analisis dilakukan sampai pada menyelidiki penyebab siswa melakukan kesalahan dalam menyelesaikan soal cerita. Penyebab inilah yang nantinya akan diatasi oleh guru agar siswa tidak melakukan kesalahan yang sama sehingga prestasi belajar matematika siswa dapat meningkat.

Beberapa penelitian analisis kesalahan menggunakan Fong's shcematic model for error analysis diantaranya Jiang (2013) hasil penelitiannya menyebutkan bahwa secara umum siswa Cina dan Singapura tidak bisa mendapatkan jawaban yang benar dalam menyelesaikan masalah. Siswa sering melakukan Incomplete Schema with Errors (skema tidak lengkap dengan kesalahan), Using Irrelevan Procedure (menggunakan prosedur yang tidak relevan), dan No Solution (Tidak ada solusi). Pada penelitiannya, Jiang (2013) hanya ingin mengetahui persentase kesalahan skema yang dilakukan siswa Cina dan Singapura tanpa membahas lebih lanjut penyebab kesalahannya.

Banyak faktor yang dapat mempengaruhi siswa dalam menyelesaikan soal cerita, diantaranya gaya kognitif, gender, tingkat kemampuan siswa. Beberapa peneliti telah menganalisis kesalahan siswa dalam menyelessaikan soal cerita berdasar gaya kognitif (Nurussata'at, dkk., 2016), gender (Kholishoh, dkk., 2017), berdasarkan tingkat kemampuan siswa (Lahinda dan Jailani, 2015). Berdasarkan pemaparan tersebut, peneliti tertarik menganalisis jenis kesalahan dan mendeskripsikan faktor-faktor yang 
menyebabkan siswa melakukan kesalahan dalam menyelesaikan soal cerita yang berkaitan dengan SPLTV berdasarkan Fong's Shcematic Model For Error Analysis berdasarkan tingkat kemampuan siswa (tinggi, sedang dan rendah).

\section{LANDASAN/KAJIAN TEORI}

\section{Soal Cerita}

Soal cerita adalah soal yang disajikan dalam bentuk cerita atau dalam bentuk kalimat yang bermakna, dan berkaitan keadaan yang dialami siswa dalam kehidupan sehari-hari yang didalamnya terdapat konsep matematika. Rahardjo dan Astuti (2011) menyatakan bahwa soal cerita yang terdapat dalam matematika merupakan soal-soal yang terkait dengan permasalahan kontekstual yang bisa dicari penyelesaiannya dengan menggunakan kalimat matematika. Soal cerita merupakan salah satu bentuk soal yang menyajikan permasalahan kontekstual dalam bentuk narasi atau cerita. Soal cerita biasanya ditulis dalam kalimat yang didalamnya termuat permasalahan yang penyelesaiannya menggunakan kemampuan berhitung (Budiyono, 2008).

Beberapa penjelasan di atas dapat disimpulkan, soal cerita matematika merupakan soal yang disajikan dalam bentuk cerita yang terjadi dalam kehidupan sehari-hari yang ada kaitannya dengan konsep matematika.

\section{Fong's shcematic model for error analysis}

Pada tahun 1993 Fong mengembangkan model analisis kesalahan. Fong (1993) mengklasifikasikan kesalahan menjadi dua tingkat. Pada tingkat pertama yaitu dalam hal pendekatan skema yang terdiri dari lima kategori yaitu: (E1) tidak ada solusi, (E2) menggunakan prosedur yang tidak relevan, (E3) skema tidak lengkap dengan kesalahan, (E4) skema tidak lengkap dengan tidak ada kesalahan, dan (E5) skema lengkap dengan kesalahan. Sedangkan pada tingkat kedua kesalahan dikategorikan menjadi empat kategori yaitu: (a) bahasa, termasuk membaca dan pemahaman, (b) operasional, termasuk kesimpulan dan transformasi, (c) tema matematika termasuk fakta-fakta dasar, algoritma, dan konsep, dan (d) faktor psikologis termasuk motivasi dan ketidaktelitian.

Metode Fong menggunakan pendekatan skema sehingga guru dapat mengetahui secara jelas apakah skema yang dilakukan siswa untuk menyelesaikan soal cerita sudah lengkap ataukah belum. Langkah pertama yang dilakukan dalam menganalisis kesalahan siswa dengan metode Fong ini adalah dengan mengelompokkan kesalahan siswa pada tingkat pertama, yaitu kategori E1 sampai dengan E5 berdasarkan indikator yang telah ditentukan pada setiap kategorinya. Pengkategorian pada tingkat pertama ini didasarkan pada pendekatan skema. Selanjutnya kesalahan siswa untuk kategori E2, E4 dan E5 dianalisis pada tingkat berikutnya untuk mengetahui penyebab siswa melakukan kesalahan. Pada tingkat kedua ini dibagi menjadi empat kategori yaitu kesalahan bahasa, operasional, tema matematika dan faktor psikologis. Kategori tersebut memiliki beberapa indikator terkait kemungkinan kesalahan yang dilakukan siswa pada setiap kategorinya (Fong, 1993).

Analisis kesalahan dengan metode Fong yang spesifik ini diharapkan mampu untuk menganalisis kesalahan siswa kelas $\mathrm{X}$ dalam menyelesaikan soal cerita terkait dengan SPLTV secara rinci dan mendalam. 
Hasil analisis tersebut dapat dijadikan bahan pertimbangan dalam merencanakan dan melaksanakan kegiatan belajar mengajar selanjutnya. Harapannya kualitas kegiatan belajar mengajar selanjutnya dapat meningkat. Kemudian, peningkatan kualitas belajar mengajar tersebut diharapkan dapat meningkatkan prestasi belajar siswa.

\section{METODE PENELITIAN}

\section{Jenis Penelitian}

Jenis penelitian ini adalah penelitian survey dengan pendekatan kualitatif. Pendekatan kuantitatif dipilih karena dapat menjelaskan suatu masalah yang hasilnya dapat digeneralisasikan. Penelitian ini dikategorikan sebagai penelitian survey karena melibatkan proses pengumpulan data untuk menjawab pertanyaan penelitian terkait dengan kesalahan yang dilakukan siswa kelas X SMA Negeri 2 Kuningan dalam menyelesaikan soal cerita SPLTV. Sehingga objek penelitian ini adalah kesalahan yang dilakukan siswa dalam menyelesaikan soal cerita pada materi SPLTV.

\section{Waktu dan Tempat Penelitian}

Waktu penelitian dilaksanakan pada bulan November 2019 seiring dengan adanya kegiatan PKM III. Untuk tempat penelitian yaitu di SMA Negeri 2 Kuningan.

\section{Subjek Penelitian}

Target penelitian adalah siswa kelas $X$. Pengambilan subjek dalam penelitian ini menggunakan teknik purposive sampling.

\section{Prosedur Penelitian}

Prosedur penelitiannya yaitu dengan mengujikan soal cerita SPLTV sebanyak 3 soal. Lalu setelah diketahui hasil pengerjaan siswa diambil 3 siswa dengan nilai rendah, sedang dan tinggi. Lalu setelah itu dibandingkan dan dianalisis kesalahannya dengan teori fong's.

\section{Data, Intrumen, dan Teknik Pengumpulan Data}

Pengumpulan data dalam penelitian ini dilakukan dengan metode dokumentasi, metode tes, dan metode wawancara

\section{Teknik Analisis Data}

Langkah-langkah analisis meliputi reduksi, penyajian, dan verifikasi data. Langkah pertama yang dilakukan dalam menganalisis kesalahan siswa dengan metode Fong ini adalah dengan mengelompokkan kesalahan siswa pada tingkat pertama, yaitu kategori E1 sampai dengan E5 berdasarkan indikator yang telah ditentukan pada setiap kategorinya. Pengkategorian pada tingkat pertama ini didasarkan pada pendekatan skema. Selanjutnya kesalahan siswa untuk kategori E2, E4 dan E5 dianalisis pada tingkat berikutnya untuk mengetahui penyebab siswa melakukan kesalahan. Pada tingkat kedua ini dibagi menjadi empat kategori yaitu kesalahan bahasa, operasional, tema matematika dan faktor psikologis. Kategori tersebut memiliki beberapa indikator terkait kemungkinan kesalahan yang dilakukan siswa pada setiap kategorinya.

\section{HASIL PENELITIAN DAN PEMBAHASAN}

Dari hasil kerja siswa, peneliti memutuskan untuk mengambil 3 siswa sebagai sampel berdasarkan tingkat kemampuannya yaitu siswa dari kelompok rendah, sedang dan tinggi. Fokus utama penelitian ini adalah untuk menganalisis kesalahan siswa berdasarkan Skema Fong's 
Error pada tingkat 1 yaitu tidak ada penyelesaian (E1), langkah penyelesaian tidak sesuai (E2), skema tidak lengkap tanpa ada kesalahan (E3), skema tidak lengkap dengan kesalahan (E4), skema lengkap dengan kesalahan (E5) dan skema lengkap tanpa ada kesalahan (B).

Berdasarkan analisis kesalahan skema fong's secara umum kesalahan tersebut dilakukan semua kelompok baik kelompok siswa kemampuan rendah, sedang mauapun tinggi. Adapun pembahasan masing-masing tipe kesalahan yang dilakukan siswa adalah sebagai berikut.

\section{Anlisis penyelesaian soal SPLTV soal nomor 1}

Berikut adalah jawaban siswa dari masing - masing kelompok

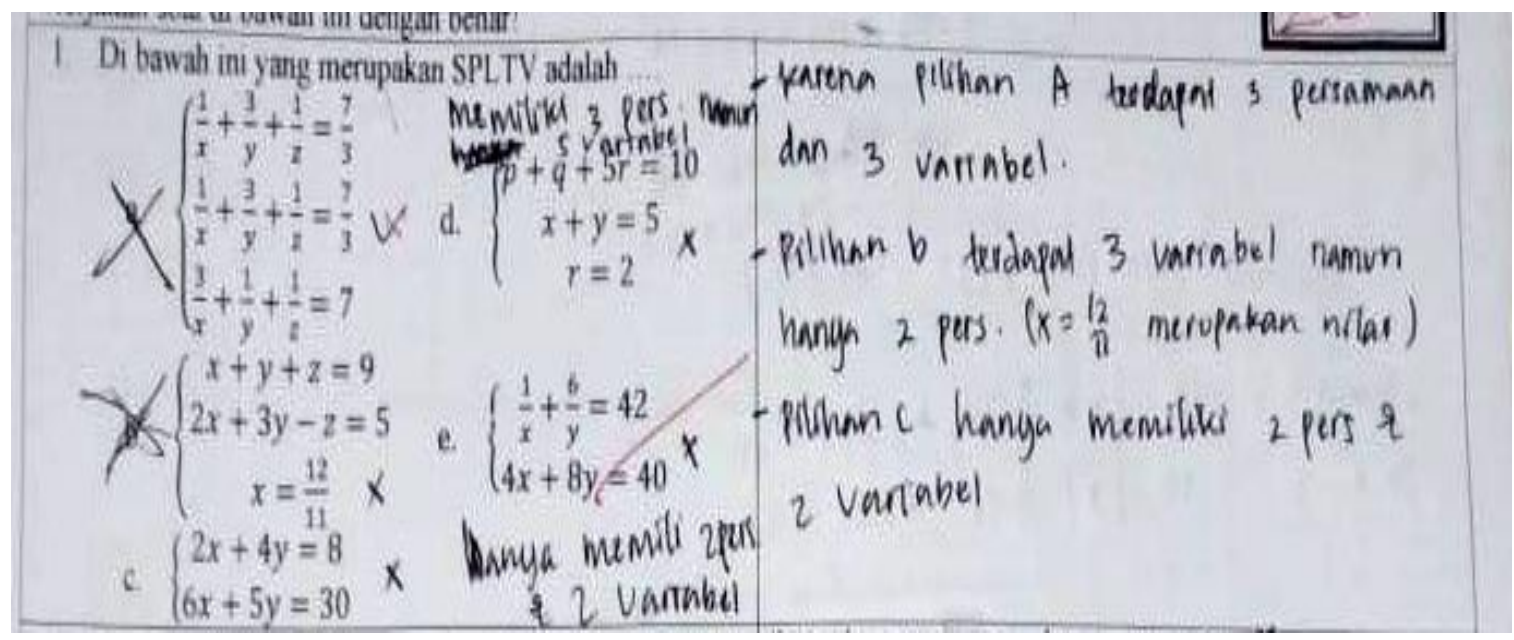

Gambar 1. Hasil Penyelesaian Siswa Kelompok Kemampuan Rendah

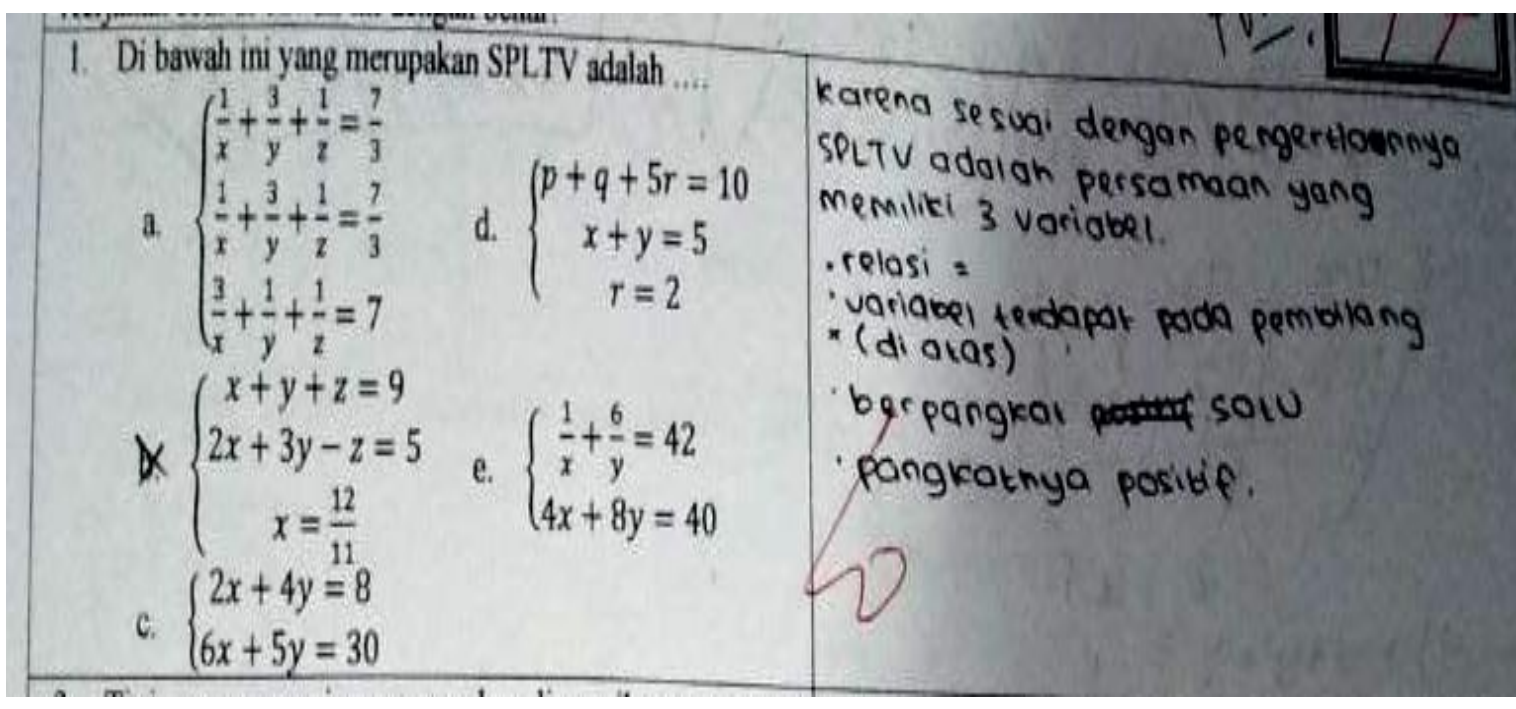

Gambar 2. Hasil Penyelesaian Siswa Kelompok Kemampuan Sedang 


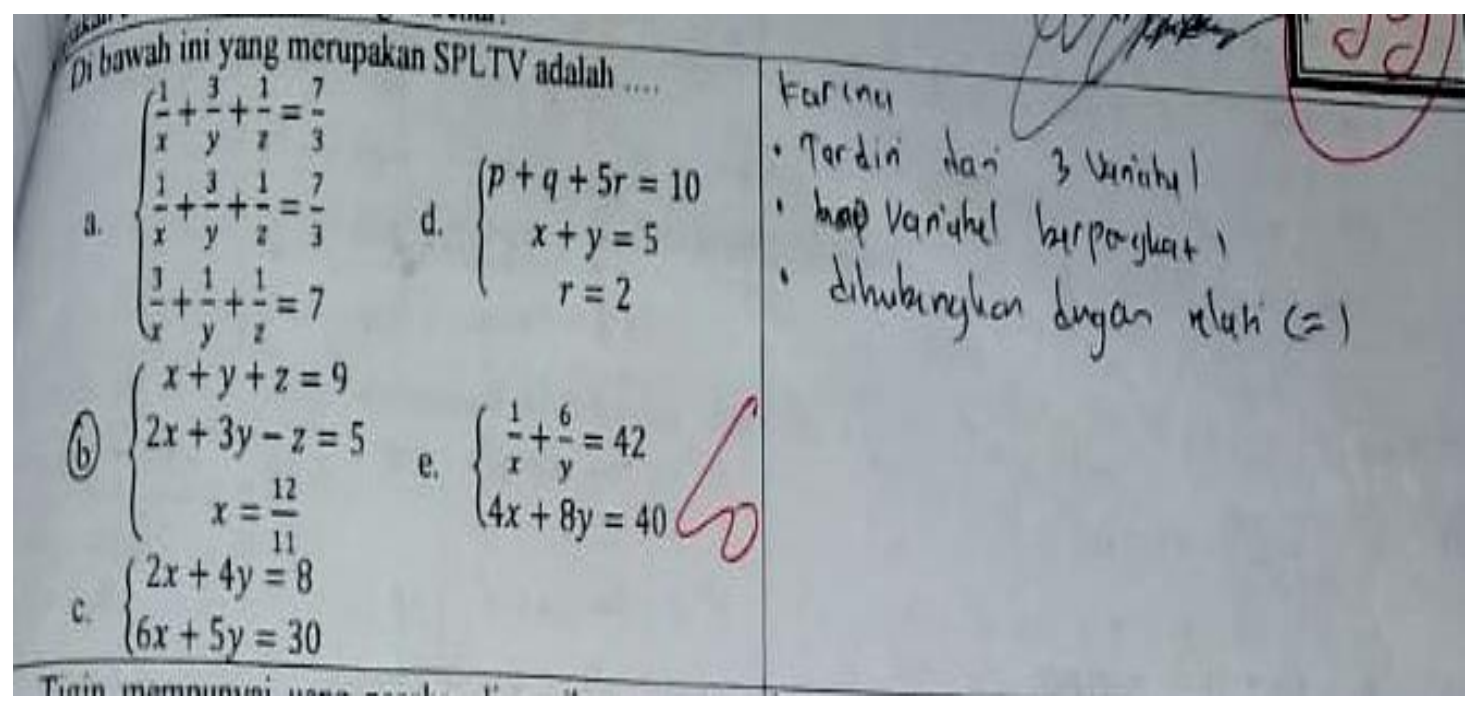

Gambar 4. Hasil Penyelesaian Siswa Kelompok Kemampuan Tinggi

Dari gambar di atas, penyelesaian siswa kelompok kemampuan rendah merupakan penyelesaian soal skema E2 yaitu meyelesaikan soal tapi dengan jawaban yang tidak sesuai. Hal ini disebabkan karena siswa tidak memahami konsep materi secara utuh. Sedangakan siswa dengan keampuan sedang dan tinggi mampu menyelesaikan soal dengan benar dan lengkap menurut skema fong's untuk penyelesaian yang lengkap dan tanpa kesalahan termasuk kedalam kategori B. Menurut siswa mereka dapat mengerjakan soal nomor 1 dengan benar karena tidak melibatkan perhitungan matematis.

\section{Analisis Penyelesaian Soal SPLTV pada soal nomor 2}

Berikut adalah jawaban siswa dari masing - masing kelompok.

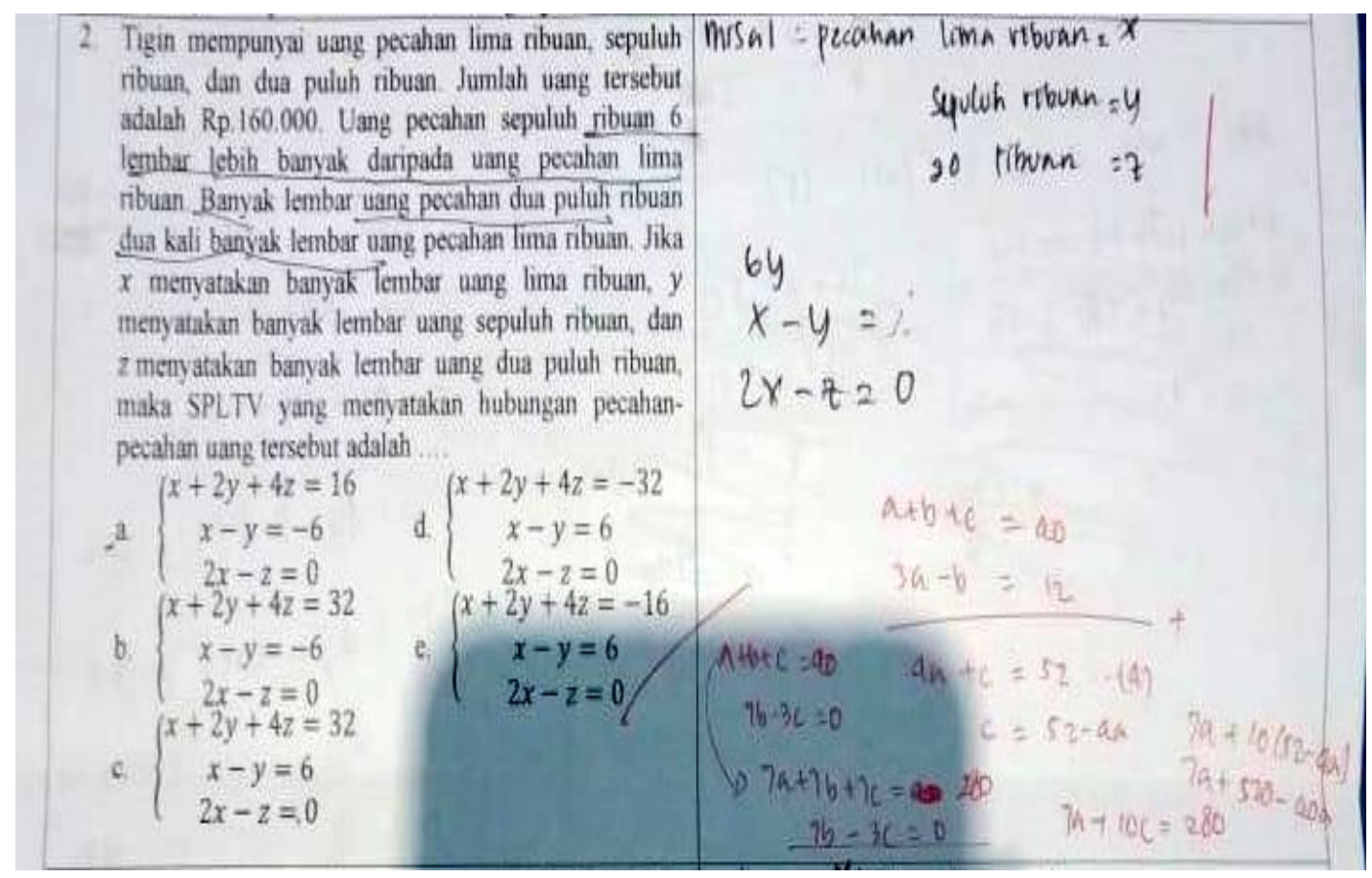

Gambar 4. Hasil Penyelesaian Siswa Kelompok Kemampuan Rendah 


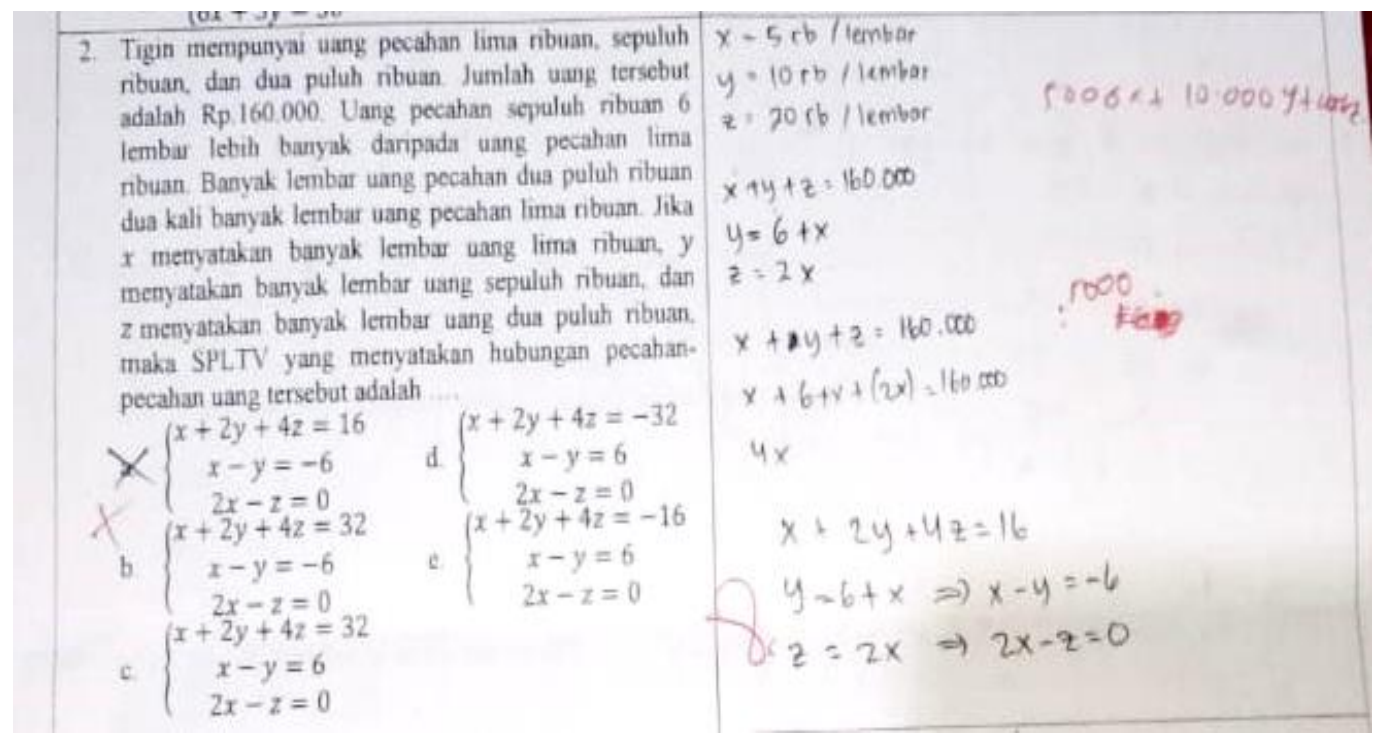

Gambar 5. Hasil Penyelesaian Siswa Kelompok Kemampuan Sedang

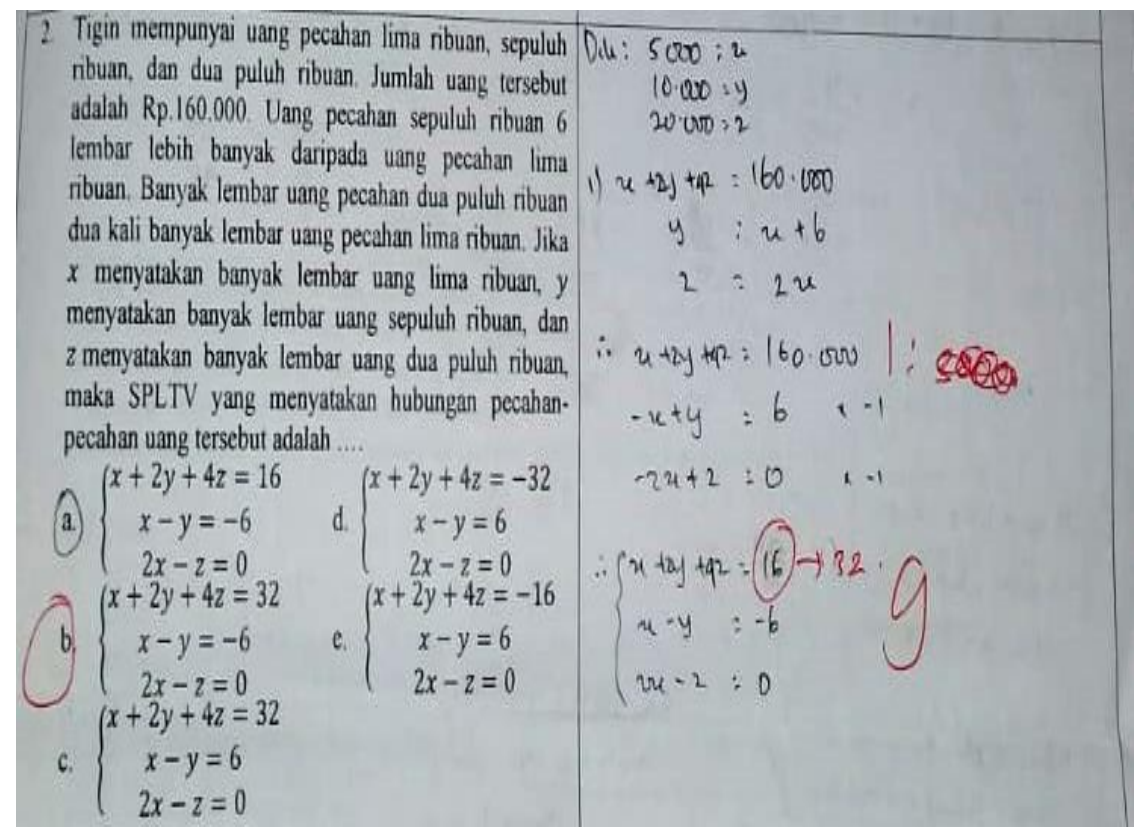

Gambar 6. Hasil Penyelesaian Siswa Kelompok Kemampuan Tinggi

Penyelesaian siswa kelompok rendah merupakan penyelesaian kategori E2 yaitu menggunakan langkah penyelesaian yang tidak sesuai. Pada gambar diatas siswa sudah dapat memahami maksud soal nomor 2 yaitu dengan memodelkan data pada soal dengan variable $\mathrm{x}, \mathrm{y}$ dan $\mathrm{z}$. menurut Amalia dkk (2018), menyelesaikan soal cerita pada SPLTV membutuhkan keterampilan dalam menterjemahkan soal cerita kedalam model matematika. Akan tetapi, pada langkah selanjutnya persamaan yang dibentuk tidak sesuai dan variablenya berganti menjadi a,b dan c. Berdasarkan wawancara alasan siswa memberikan penyelesaian seperti pada gambar di atas dikarenakan siswa tidak memahami maksud dari soal yang diberikan. Hal ini sesuai dengan Mountague (2014) seorang 
pemecah masalah tidak mungkin dapat memecahkan masalah yang diberikan tanpa diawali dengan penafsiran masalah secara tepat.

Hasil penyelesaian siswa kelompok sedang dan tinggi termasuk kedalam skema E5 yaitu penyelesaian soal lengkap dengan kesalahan. Pada gambar terlihat bahwa siswa sudah menyelesaikan soal pada tahap memahami masalah, merencanakan penyelesaian dan menyimpulkannya. Tapi terdapat kesalahan dalam komputasinya sehingga hasil yang diperoleh tidak sesuai.
Berdasarkan wawancara hal ini disebabkan karena siswa terburu - buru dalam menyelesikan soal. Menurut Amalia,dkk (2018), salah satu faktor yang menyebabkan terjadinya kesalahan siswa dalam menyeslaikan soal cerita SPLTV adalah siswa tergesa-gesa dalam menyelesaikan soal.

\section{Analisis Penyelesaian Soal SPLTV pada soal nomor 3}

Berikut adalah jawaban siswa dari masing - masing kelompok.

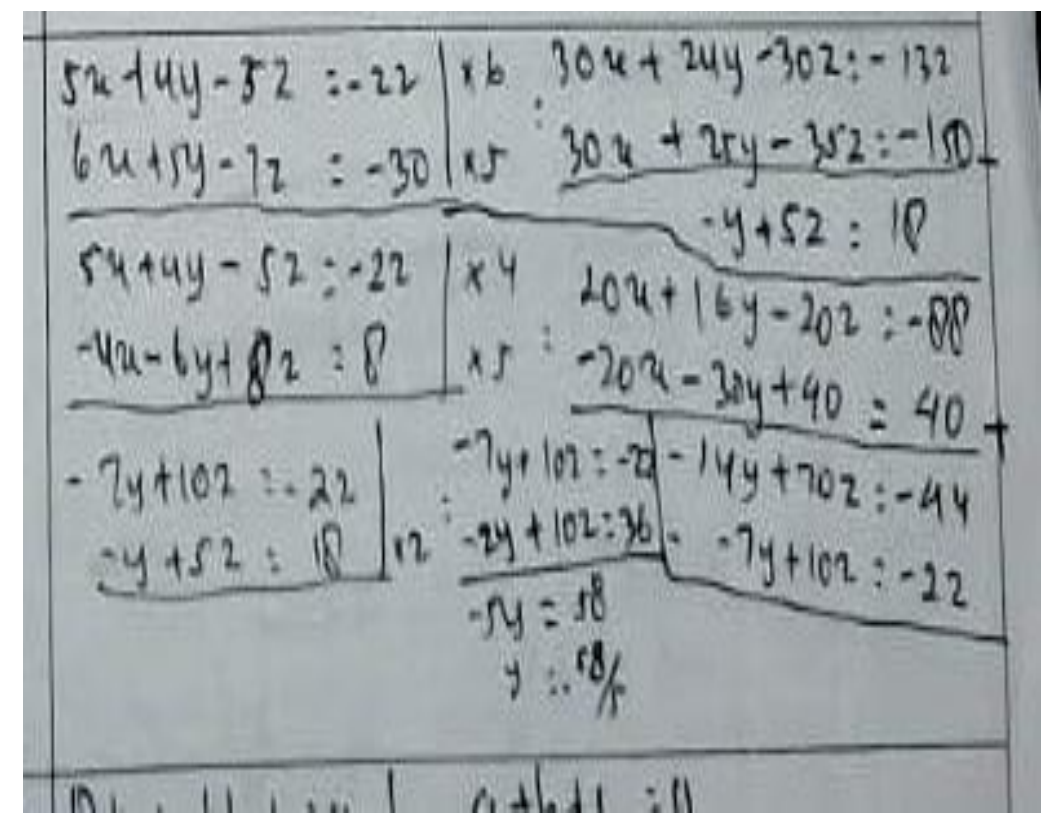

Gambar 7. Hasil Penyelesaian Siswa Kelompok Kemampuan Rendah 


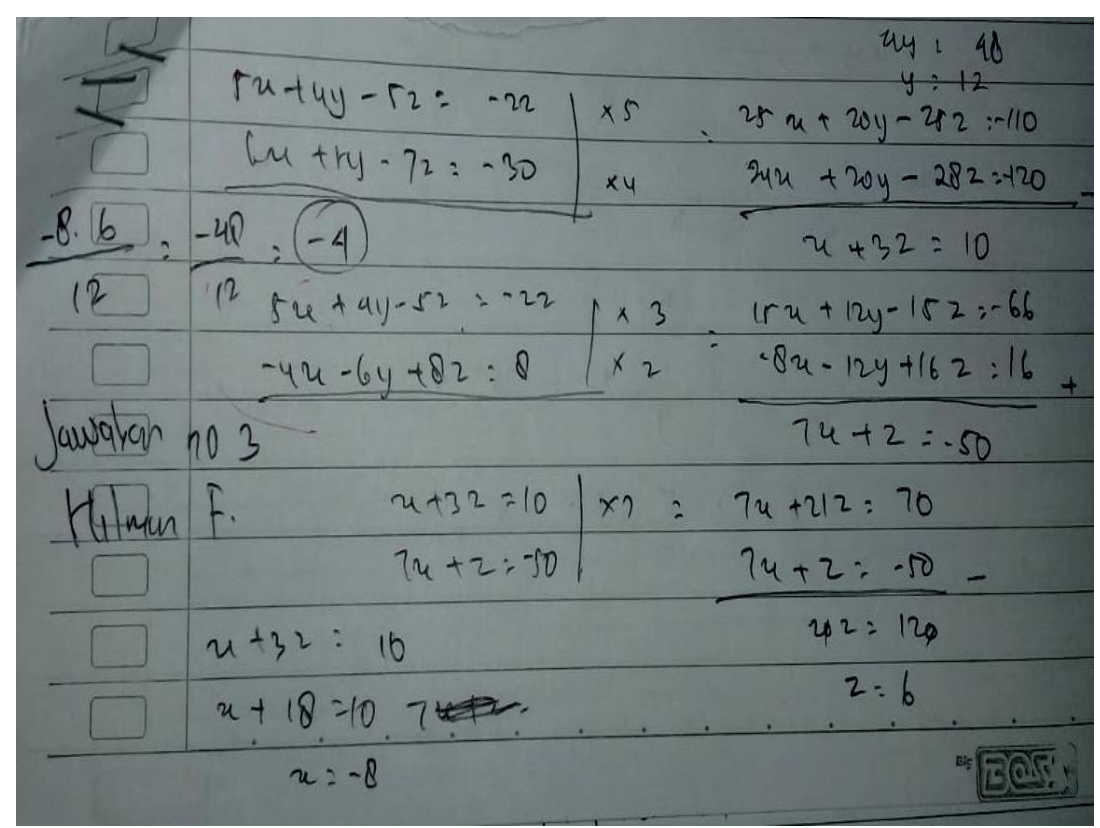

Gambar 8. Hasil Penyelesaian Siswa Kelompok Kemampuan Sedang

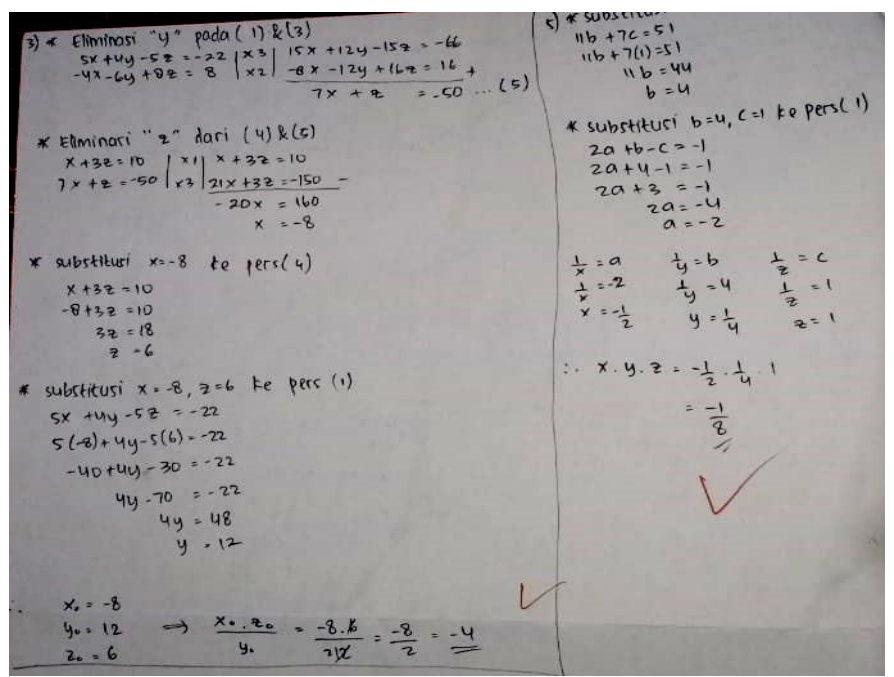

Gambar 9. Hasil Penyelesaian Siswa Kelompok Kemampuan Tinggi

Berdasarkan pada gambar, siswa kelompok kemampuan rendah tidak memberikan skema penyelesaian yang lengkap dan tidak tepat. Siswa tidak menuliskan data yang ada pada soal, siswa hanya mengeliminasi persamaan yang terdapat pada soal tanpa penyelesaian yang jelas. Menurut skema Fong's penyelesaian pada gambar 7 merupakan skema E2.

Penyelesaian siswa kelompok kemampuan sedang, siswa telah memahami maksud soal tetapi skema penyelesaiannya tidak lengkap karena siswa tidak menuliskan data yang ada pada soal. Berdasarkan wawancara siswa mengatakan bahwa data yg diberikan sudah jelas pada soal sehingga tidak perlu lagi menuliskannya pada penyelesaian yang dikerjakan.

Dari gambar diatas, penyelesaian siswa kelompok kemampuan tinggi sudah dengan skema yang lengkap tanpa ada kesalahan. Siswa memulai dengan menuliskan data yg ada pada soal, 
merencanakan penyelesaian masalah dan memberikan kesimpulan. Maka menurut skema Fong's penyelesaian siswa kelompok tinggi merupakan skema B yaitu skema lengkap dan tanpa ada kesalahan. Berdasarkan wawancara, alasan mengerjakan penyelesaian soal secara lengkap karena siswa sudah terbiasa mengerjakan soal secara sistematis.

Berdasarkan hasil analisis diatas siswa pada kelompok kemampuan rendah, dominan menyelesainkan soal dengan langkah/prosedur yang tidak sesuai atau masuk pada kategori E2. Hal ini sesuai dengan penelitian Lahinda dan Jailani (2015) yang menyatakan bahwa siswa pada kelompok kemampuan rendah cenderung lebih banyak mengalami kesalahan jika dibandingkan dengan siswa pada kelompok kemampuan sedang dan tinggi. Sedangkan siswa dengan kemampuan sedang berada pada kategori E5 dan siswa pada kelompok kemampuan tinggi terdapat pada kategori E5 dan B.

\section{SIMPULAN DAN SARAN Simpulan}

Berdasar hasil analisis data dapat disimpulkan bahwa jenis kesalahan siswa dalam menyelesaikan soal cerita adalah kesalahan operasional dan tema matematika. Faktor penyebab kesalahan siswa antara lain: terburu-buru ingin segera menyelesaikan soal, kurang teliti, kebiasaan saat mengerjakan soal, lupa, kurang memahami soal, dan kurang memahami materi.

\section{Saran}

Berdasarkan simpulan yang dibuat untuk menyelesaikan soal cerita pada materi SPLTV disarankan untuk melakukan tindakan-tindakan:
1. Alternatif pemecahan masalah pada jenis kesalahan bahasa, antara lain: guru hendaknya membiasakan siswa untuk menuliskan jawaban selengkap mungkin, guru harus memberikan penilaian secara objektif dan menyeluruh dalam menyelesaikan soal cerita.

2. Alternatif pemecahan masalah pada jenis kesalahan operasional, antara lain: guru hendaknya menekankan siswa untuk teliti dalam melakukan berbagai operasi perhitungan, pengecekan jawaban setiap soal dan teliti dalam mengerjakan soal.

3. Alternatif pemecahan masalah pada jenis kesalahan tema matematika, antara lain: guru meningkatkan penguasaan materi siswa terhadap kompetensi dasar yang dipelajari beserta materi prasyaratnya. Guru tidak menggunakan soal pilihan ganda saja, tetapi baiknya diberikan soal uraian dalam bentuk cerita, guru memperkaya pengetahuaan siswa tentang banyaknya solusi yang digunakan untuk menyelesaikan suatu soal sehingga siswa tidak terpaku pada satu cara saja.

\section{DAFTAR PUSTAKA}

Amalia, R., Aufin, M., Khusniah, R. (2018). Analisis kesalahn dalam menyelesaikan soal cerita pada pokok bahasan persamaan linier berdasarkan Newman Kelas X-Mia di SMA Bayt Al-Hikmah Kota Pasuruan. Prosiding SNMPM II, Prodi Pendidikan Matematika, Unswagati Cirebon. pp. $346-359$.

Badriyah, Lailatul, dkk. (2017). Analisis Kesalahan Dan Scaffolding Siswa Berkemampuan Rendah Dalam Menyelesaikan Operasi Tambah Dan 
Kurang Bilangan Bulat. Jurnal Pendidikan: Teori, Penelitian, \& Pengembangan, 2(1), pp. 50-57.

Baroody, A, J. (1993). Problem Solving, Reasoning, and Communicating, K-8. New York: Macmillan Publishing Company.

Budiyono. (2008). Kesalahan Mengerjakan Soal Cerita Dalam Pembelajaran Matematika. Vol.11 Solo, 2008. Hal.2. Paedagogia, Jurnal penelitian pendidikan, 11(1), pp. $1-8$.

Chapman, O. (2006). Classroom Practices for Context of Mathematics Word Problems. Educ Stud Math 62, 211230. https://doi.org/10.1007/s10649006-7834-1

Farida, N. (2015). Analisis Kesalahan Siswa SMP Kelas VII Dalam Menyelesaikan Masalah Soal Cerita Matematika. Aksioma Jurnal, 4(2), pp. 42-52.

Fong, K. (1993). Schematic model for categorizing children's errors in mathematics. Third Misconception Seminar Proceedings, pp. 1-28.

Jiang, C. (2013). Errors in solving word problems about speed: A case in Singapore and mainland China. China: University of Macau

Kholishoh, F. N., Pramudya, I., Kurniawati, I. (2017). Analisis Kesalahan Dalam Menyelesaikan Soal Cerita Dengan Fong's Schematic Model For Error Analysis Pada Materi Volume Prisma Dan Limas Ditinjau Dari Gender Siswa Kelas VII E SMP Negeri1 Kartasura Tahun Ajaran 2015/2016. Jurnal Pendidikan Matematika dan Matematika Solusi. 1(1), pp. $16-35$.

Lahinda, Y dan Jailani. (2015). Analisis proses pemecahan masalah matematika siswa sekolah menengah pertama. Jurnal Riset Pendidikan Matematika, 2(1), pp. 148-161.

Magfirah, dkk. (2019). Analisis Kesalahan Siswa Dalam Menyelesaikan Soal Cerita Matematika Berdasarkan Prosedur Newman. Lentera Sriwijaya Jurnal Ilmiah Pendidikan Matematika, 1(2), pp. 1-12.

Montague, M., Krawec, J., Enders, C., \& Dietz, S. (2014). The Effects of Cognitive Strategy Instruction on Math Problem Solving of MiddleSchool Students of Varying Ability. Journal of Educational Psychology, 106(2), pp. 469.

Nurussafa'at, F., A., Sujadi, I., Riyadi. (2016). Analisis kesalahan siswa dalam menyelesaikan soal cerita pada materi volume prisma dengan Fongs's schematic model for error analysis ditinjau dari gaya kognitif siswa. Jurnal Elektronik Pembelajaran Matematika, 4(2), pp. 174-187.

Priyanto, A, dkk. (2015). Analisis Kesalahan Siswa dalam Menyelesaikan Soal Cerita Matematika. Artikel ilmiah mahasiswa, 1(1), pp. 1-5.

Rahardjo, M dan Astuti, W. (2011). Pembelajaran Soal Cerita Operasi. Hitung Campuran di Sekolah Dasar. [Online]. Tersedia: http://www.p4tk

Rahayu, P. (2018). Analisis kesalahan siswa SMP dalam menyelesaikan soal SPLDV. Prosiding Seminar nasional Etnomatnesia, UST, Yogyakarta. Pp. $331-340$.

Rahayuningsih, P \& Qohar, A. (2014). Anlaisis kesalahan menyelesaikan soal cerita sistem persamaan linier dua variabel (SPLDV) dan scaffoldingnya berdasarkan analisis kesalahan Newman pad siswa kelas VII SMP Negeri Malang. Jurnal Pendidikan Matematika dan Sains, 2(2), pp. 109116. 
